\title{
Discovery Learning and Problem-Based Instructional Approaches: Effect of Secondary School Students' Interest in Biology
}

\author{
EJEH Chantal Ijeoma ${ }^{1}$, AKUDOLU, Lilian Rita ${ }^{2}$ \\ ${ }^{1}$ Asagba Mixed Secondary School, Asaba, Delta State \\ ${ }^{2}$ Department of Educational Foundations, Faculty of Education, Nnamdi Azikiwe University, Awka
}

\begin{abstract}
The study investigated the effect of discovery learning and problem-based instructional approaches on secondary school students' interest in Biology. Three research questions and four hypotheses guided the study. The study adopted the quasi-experimental design for the study. The population of the study was 753 senior secondary school year two (SS2) biology students in Oshimmili North local government area of Delta state. A sample of 159 SS 2 biology students was involved in the study. The instrument for data collection wasBiology Interest Scale (BIS)validated by lecturers in the Department of Science Education, Nnamdi Azikiwe University, Awka and Delta State University, Abraka and one experienced secondary school biology teacher. The reliability of BISwas established using Cronbach Alpha to be 0.93. Data collected by administering the instruments as pretest and posttest before and after treatment were analyzed using mean, standard deviation and analysis of covariance. The finding of the study revealed that there was significant difference between the mean interest scores of the students taught using discovery learning, problem-based instruction and conventional method in favour of discovery learning followed by problem-based learning. The study recommended that orientation and seminars should be organized by school administrators for biology teachers to aid them in the mastery of discovery and problem-based learning and how to integrate them in the learning process of biology.
\end{abstract}

Keywords: Discovery, problem-based, learning, biology, interest

\section{INTRODUCTION}

$\mathrm{L}$ earning to solve problem is the most important skill that students can acquire in any setting. This is because, in professional contexts, people are paid to solve problems. In everyday life, we constantly solve problems. We face problems, big and small, simple and complex, clear and confusing in our everyday life. It is important to note however, that an individual may discover the solution to a problem but is often in need of others to solve the problem effectively. Above all, solutions to problems are quickly deciphered if individuals work together to achieve a common goal. Thus, discovery and ability to solve problems are necessary for science study such as biology.

Biology according to Campbell (2015) is the science of life or living matter in all its forms and phenomena, especially with reference to origin, growth, reproduction, structure, and behaviour. Biology probes into many specialized fields that cover morphology, physiology, anatomy, behaviour, origin, and distribution. The study of Biology in higher education is divided into different fields. Among the fields as outlined by Mader (2017) are Botany which is the study of plants; Zoology, the study of animals; Medicine, the study of health, Palaeontology, the study of extinct life; Anatomy, the study of shape and structure of animals and plants; and Biochemistry, the study of the chemistry of living organism. The study of Biology also includes biogeography which studies how life is distributed across the planet.

Developmental Biology studies embryo developing from cell to independent organism; Ecology studies things in relation to each other and to their environment; Micro Biology studies microorganism; Genetics explores the science of inheritance, how genes are expressed and the structure and function of biological important molecule; Pathology delves into diseases and how to cure them, Pharmacology, studies drugs and medicine and how they affect the body; and Physiology studies of biological processes. All these are also fields of Biology which indicates that biology is important.

Despite the popularity of biology as a subject in secondary school level of education, students' interest and the number of students enrolling for the subject in external examination is beginning to dwindle given that it is no longer a compulsory subject (Datom, 2015). One of the reasons for the reduction in students' interest in biology has been related to the lack of active role in their learning. When students are given responsibility for their own learning through problem solving, not only does achievement improve but also their interest to learning is enhanced.

Interest is a kind of consciousness accompanying and stimulating attention, a feeling, pleasant or painful directing attention towards an action or object. Interest is a motivational factor that drives the will to perform an action. For learning to be of interest to students, these students must meaningfully learn the concept taught. Also, they should assume active role in their own learning or be challenged in a positive way to learn the concepts taught. The lack of interest to learn not only affects the students during the learning process but also results in poor achievement. With the spate of poor achievement in biology, the researcher is poised therefore, to conduct a study 
using problem-based and discovery learning to see if they could improve students' interest in Biology.

Discovery learning (DL) is simply a learning situation in which the principal content of what is to be learned is not given, but must be independently discovered by the learner, making the student an active participant in his learning (Mattingly, Lutkehaus, \& Throop, 2008). Discovery learning (DL) encompasses an instructional model and strategies that focus on active, hands-on learning opportunities for students. DL approach is characterized by active exploration and integration of experience and ideas(Oziokor, 2015). It is a kind of teaching that is based on the student finding things out for themselves, looking into problems, and asking questions. Essentially, it is all about students coming to their own conclusions and asking about things in their subjects that might not make particular sense.

Discovery learning according to Alfieri, Brooks, Aldrich, and Tenenbaum (2011) can be unguided or guided. Alfieri et al. (2011) noted that unguided discovery learning is a type of discovery learning whereby the teacher provides little or no assistance. In guided discovery learning, the teacher provides the students with directive and is open to questions relating to issues of their discovery. According to Udo (2010) guided discovery approach involves engaging the learners in simple experimental activities (structured or unstructured) involving genuine 'Lets' find out' exercises under the assistance of the teacher. Guided-discovery is a teaching method, that enable learners create their own learning experience, with the guidance of their teacher. A guided-discovery method involves an unstructured exploration in some problem-based experiences in which students can draw general conclusions from data gathered through measuring, classifying, inferring, predicting, communicating, analyzing, clarifying, describing and formulating relevant questions (Oziokor, 2015). The guided discovery learning approach was adopted in this study because of its potential to arouse and sustain students' interest in learning just as problem-based learning.

Problem-based learning/ Instruction (PBL) according to Barrows (2000) is an active learning method based on the use of structured problems as a stimulus for learning. Structured problems are complex problems that cannot be solved by a simple algorithm (Barrows, 2000). Such problems do not necessarily have a single correct answer but require learners to consider alternatives and to provide a reasoned argument to support the solution that they generate. In PBL students use the problem to direct them to research and learn the new knowledge needed (Erickson, Peters \& Strommer, 2006). One of the key elements that sets PBL apart from other methods is that the problem comes before instruction on the knowledge needed for the problem. Typically, the student applies new knowledge covered through instruction to solve a problem. Problem-based learning (PBL) is an instructional method in which students learn through facilitated problem solving. Students work in collaborative groups to identify what they need to learn in order to solve a problem.Thus, PBL method is carried out in small, facilitated groups, taking advantage of the social aspect of learning through discussion and study with peers (Hmelo-Silver, 2004).

Many empirical studies which examined the effectiveness of problem-based learning in various contexts concluded that problem-based learning enhances students' problem solving, higher order thinking, self-directed learning skills, and motivation to learn (Zejnilagic-Hajric, Sabeta \& Nuic, 2015). Also, problem-based learning students consistently performed better than traditional students on long-term retention assessments (Jonassen \& Hung, 2012). Problem-based learning can be effectively applied in Biology education, especially in practical part of the subject. The practical is an important component of science education that can foster positive attitudes and interest towards science. Students irrespective of their gender can learn not only scientific concepts, but also scientific thinking abilities, and experimental skills (Yoon, Woo, Treagust, \& Chandrasegaran, 2014).

Gender issues in science learning have remained inconclusive. While some studies validate that gender has significant influence on students' achievement in Biology, others found different results under different experimental conditions. There is the need to further investigate whether discovery learning and problem-based instruction may improve students' achievement and interest in Biology without gender bias.

\section{Purpose of Study}

The study focused on the effect of discovery learning and problem-based instructional approach on secondary school students' interest in biology. Specifically, the study sought to:

1. Compare the mean interest scores of students in biology taught using. discovery learning and problem-based learning and those taught using conventional method.

2. Establish whether the mean interest scores of male and female students in Biology taught using discovery learning would differ.

3. Examine the difference in the mean interest scores of male and female students in Biology taught using problem based learning.

4. Determine the interaction effect of teaching methods and gender on interest of students in Biology.

\section{Research Questions}

The following research questions guided the study.

1. What are the mean interest scores of students taught biology using discovery learning and problem-based learning and those taught using conventional method?

2. What are the mean interest scores of male and female students taught Biology using discovery learning? 
3. What are the mean interest scores of male and female students taught Biology using problem based learning?

\section{Hypotheses}

The following null hypotheses were tested at 0.05 level of significance:

1. There is no significant difference in the mean interest scores of students in biology taught using discovery learning and problem-based learning and those taught using conventional method?

2. There is no significant difference in the mean interest scores of male and female students in Biology taught using discovery learning?

3. There is no significant difference in the mean interest scores of male and female students in Biology taught using problem based learning?

4. There is no significant interaction effect of teaching methods and gender on interest of students in Biology.

\section{METHOD}

The design of this study is quasi-experimental. Specifically, the pre-test, post-test, non-equivalent control group design was used. This design is one that seeks to establish the cause and effect relationship between the variables of interest in a study without randomization of subjects into group. Udo (2010)also noted that in quasi-experimental design, intact classes are used. The design was chosen since the administrative set up in school may not allow for randomization of students which may disrupt normal school activities and therefore requires the use of only intact classes.

The area of the study is Oshimili North Local Government Area of Delta State. Oshimili North is one of the nine local government areas in Delta North Senatorial District of Delta state. The indigenes of the Local Government are Anioma people but each of the communities comprising the Local Government has its distinct history of origin. The people of this region speak Igbo. The people of Oshimili North are mostly farmers with steady and ready markets for their produce. This area is chosen for the study because there are enough farm settlements to serve as academic resource centres. The farm settlements will be used for conducting discovery learning. Problems relating to the concepts will be constructed with a view of what obtains in those farms.

\section{Population}

The population of the study consists of all the 853 senior secondary school year two (SS2) students in the 10 public secondary schools in Oshimmili North local government area of Delta state. There are nine public co-educational and one single sex secondary schools in Oshimili North Local Government Area.

Sample Size
The sample of the study is 159 (85 males, 74 females) SS2 Biology students. From the co-educational schools, purposive sampling was used to select three schools. The rational for selecting the schools was because they are far apart and prevented class interaction which may lead to subject contamination. Simple random sampling was used to assign the school to experimental groups I and II and the control group. In each school selected, SS2 Biology students were used. In the school assigned as experimental group I, there were 22 males and 21 females. Experimental group II had 37 males and 24 females while the control group had 26 males and 29 females.

\section{Instrument for Data Collection}

The instrument for data collection is Biology Interest Scale (BIS) adopted from Biology Interest Scale used by Onwuegbunam (2016). BIS contained 20 items scale adopted from Onwuegbunam (2016) to generate information of the students' interest in Biology (see Appendix D, p. 98 on BIS). The instrument was designed on a four point Linkert scale of strongly agree (SA), agree (A), disagree (D) and strongly disagree (SD). The instrument also generated information on the students' gender. Also, instructional plans were developed for the experimental groups and control groups using discovery learning, problem-based approach. The lesson notes of the lesson teacher from the conventional method school was used to ensure uniformity of contents in what will be taught.

The initial draft of the BIS and lesson plans along with the objectives, research questions and hypotheses were given to a lecturer in the Department of Science Education, Nnamdi Azikiwe University Awka and another lecturer in the Delta State University, Abraka, and an experienced Biology teacher. The validators were requested to vet the instruments in terms of: suitability of the language, relevance of each item to student's level, and any other consideration outside the ones indicated. They were also required to write ' $R$ '-retain, ' $M$ 'Modify, 'D'-Delete against questions that should be retained, modified or deleted.Their corrections and recommendations were effected in the final copy of the instrument.

The reliability of the instrument was established using Cronbach's Alpha for BIS. Cronbach's Alpha was used for BIS since the items in the instrument are polytomously scored. The instruments were administered to 40 Biology students in the Institute of Continuous Education (ICE), Asaba. The generated scores were computed for reliability using BIS. The coefficient of internal consistency obtained for BIS was 0.93 .

The teaching of the students was preceded by a pretest using BIS. The activities that were carried out by the teachers of each instructional method are outlined as follows. Students were placed into groups of 4-6 students. In each group, a group leader was appointed who coordinated the affairs of the group. Activities of the group were made known to the teacher through the group and during each lesson, 
students of the same group were made to arrange their seats in such a way that they can seat together and share ideas. No student was allowed to select his or her own group members.

In the experimental classrooms where discovery learning and problem-based instructional strategies was applied, the following steps as recommended by Wood (1975) respectively was followed.

Discovery learning classroom: The teacher in the discovery learning class incorporated the following basic processes of discovery learning into the group's experience: a) observing, b) classifying, c) measuring, d) predicting, e) describing and f) inferring as recommended by wood (1975). The basic step that was adopted by teachers in the discovery-learning group as recommended by Wood are as follows:

a. Defining the Problem: Teacher helped students define the problem by asking thought provoking questions. This enhanced students' in-depth understanding of the problem and also enable them state feasible hypothesis that guided their discovery of the solution to the problem.

b. Guiding students plan where and how to gather data and information: Teacher gave students directives on where to get information, ensure the availability of necessary materials that can enable the students to gather and interpret data in the quest of solving the problem.

c. Students' presenting of findings through graphs, charts, models, and writing. Teacher evaluated students' discoveries to ensure that they are in accordance with scientific ideas. The teacher pointed out misconceptions and wrong ideas while communicating to the students the right information which they could not discover.

Problem Solving Classroom: In the problem-based classroom, the teacher who taught the students performed the following activities by applying the approaches recommended by Wood (1975). The approaches consist of the following:

1. Beginning with a task embedded in a familiar setting

2. Introducing problem-based techniques that might be applicable

3. Allowing students to create their own paths to a solution

4. Emphasizing collaborative learning and problem solving

5. Helping to develop collaborative working skills

6. Providing different roles for individuals in a group setting

7. Identifying, confronting and discussing misconceptions.

In both of these methods, problems and discoveries were done in groups. The activities were carried out in groups but the assessments and evaluations were done on individual basis to ensure active participation of each member of any group.

In the control group, the students were taught the same content by the classroom teacher who did not use discovery learning or problem-based approach but conventional method.
All three groups were administered with a posttest after the four weeks of teaching.

BIS was administered to the students as pretest in the first week before the commencement of the treatment. Their scores were collated and organized for analysis. Data relating to the research questions were analyzed using mean and standard deviations. The standard deviation was used to describe the variation of scores or how clustered the students' scores are distributed around the mean. The hypotheses were tested using analysis of covariance (ANCOVA) to eliminate initial group difference. Where a significant effect of the treatment is observed for hypotheses 1 and 4, a Post-Hoc analysis was carried out to indicate the order of significant difference. For the hypotheses, the decision rule is that when the probability value (P-value) is less than 0.05 , the null hypothesis was rejected; otherwise, the null hypothesis was not rejected.

\section{RESULTS}

Research Question 1: What are the mean interest scores of students taught biology using discovery learning and problembased learning and those taught using conventional method?

Research question one was answered using mean and standard deviation and presented in Table 1.

Table 1: Pretest and Posttest Mean Interest Scores of Students taught Biology using Discovery Learning (DL), Problem-based Learning (PBL) and Conventional Method (CM)

\begin{tabular}{|c|c|c|c|c|c|c|}
\hline $\begin{array}{c}\text { Source } \\
\text { of } \\
\text { Variation }\end{array}$ & N & $\begin{array}{c}\text { Pretest } \\
\text { Mean }\end{array}$ & $\begin{array}{c}\text { Posttest } \\
\text { Mean }\end{array}$ & $\begin{array}{c}\text { Gain } \\
\text { in } \\
\text { Mean }\end{array}$ & $\begin{array}{c}\text { Pretest } \\
\text { SD }\end{array}$ & $\begin{array}{c}\text { Posttest } \\
\text { SD }\end{array}$ \\
\hline DL & 43 & 24.65 & 74.77 & 50.12 & 7.10 & 3.61 \\
\hline PBL & 61 & 20.82 & 64.84 & 44.02 & 7.48 & 10.72 \\
\hline CM & 55 & 18.55 & 48.73 & 30.18 & 6.85 & 2.76 \\
\hline
\end{tabular}

Table 1 reveals that the students taught biology using discovery learning has gain in mean interest score of 50.12 while those taught using problem-based learning has gain in mean interest score of 44.02 where those taught using conventional method has gain in mean interest score of 30.18 . In the pretest, students taught using problem-based learning had the highest spread of score (7.48). Again in the posttest, the spread of scores was highest among the students taught using problem-based learning (10.72).

Research Question 2: What are the mean interest scores of male and female students taught Biology using discovery learning?

Research question two was answered using mean and standard deviation and presented in Table 2.

Table 2: Pretest and Posttest Mean Interest Scores of Male and Female Students taught Biology using Discovery Learning

\begin{tabular}{|c|c|c|c|c|c|c|}
\hline Gender & N & $\begin{array}{c}\text { Pretest } \\
\text { Mean }\end{array}$ & $\begin{array}{c}\text { Posttest } \\
\text { Mean }\end{array}$ & $\begin{array}{c}\text { Gain } \\
\text { in } \\
\text { Mean }\end{array}$ & $\begin{array}{c}\text { Pretest } \\
\text { SD }\end{array}$ & $\begin{array}{c}\text { Posttest } \\
\text { SD }\end{array}$ \\
\hline Male & 22 & 24.55 & 74.77 & 50.22 & 7.39 & 3.61 \\
\hline Female & 21 & 24.76 & 74.76 & 50.00 & 6.98 & 3.70 \\
\hline
\end{tabular}


Table 2 shows that male students taught using discovery learning has gain in mean interest score of 50.22 while the females have gain in mean achievement score of 50.00. There was higher spread of scores in the posttest among the females (3.70) than among the males (3.61).

Research Question 3: What are the mean interest scores of male and female students taught Biology using problem based learning?

Research question three was answered using mean and standard deviation and presented in Table 3.

Table 3: Pretest and Posttest Mean Interest Scores of Male and Female Students taught Biology using Problem-based Learning

\begin{tabular}{|c|c|c|c|c|c|c|}
\hline Gender & N & $\begin{array}{c}\text { Pretest } \\
\text { Mean }\end{array}$ & $\begin{array}{c}\text { Posttest } \\
\text { Mean }\end{array}$ & $\begin{array}{c}\text { Gain } \\
\text { in } \\
\text { Mean }\end{array}$ & $\begin{array}{c}\text { Pretest } \\
\text { SD }\end{array}$ & $\begin{array}{c}\text { Posttest } \\
\text { SD }\end{array}$ \\
\hline Male & 37 & 20.27 & 71.49 & 51.22 & 7.81 & 2.32 \\
\hline Female & 24 & 21.67 & 54.58 & 32.91 & 7.02 & 10.52 \\
\hline
\end{tabular}

Table 3 shows that male students taught using problem-based learning has gain in mean interest score of 51.22 while the females have gain in mean interest score of 32.91. There was higher spread of scores in the post-test among the females (10.52) than among the males (2.32).

Hypothesis 1: There is no significant difference in the mean interest scores of students in biology taught using discovery learning and problem-based learning and those taught using conventional method.

Hypothesis one was answered using analysis of covariance and presented in Table 4.

Table 4: ANCOVA on test of Significant Difference in the Mean Interest Score of Students taught Biology using Discovery Learning, Problem-based Learning and those taught using Conventional Method

\begin{tabular}{|c|c|c|c|c|c|c|}
\hline $\begin{array}{c}\text { Source } \\
\text { of } \\
\text { variation }\end{array}$ & SS & Df & MS & F & $\begin{array}{c}\text { P- } \\
\text { valu } \\
\mathrm{e}\end{array}$ & $\begin{array}{c}\text { Decisio } \\
\mathrm{n}\end{array}$ \\
\hline $\begin{array}{c}\text { Correcte } \\
\text { d Model }\end{array}$ & $17208.335^{\mathrm{a}}$ & 3 & 5736.112 & 113.445 & .000 & \\
\hline Intercept & 64419.034 & 1 & $\begin{array}{c}64419.03 \\
4\end{array}$ & $\begin{array}{c}1274.03 \\
5\end{array}$ & .000 & \\
\hline Pretest & 19.681 & 1 & 19.681 & .389 & .534 & \\
\hline Method & 15935.981 & 2 & 7967.991 & 157.585 & .000 & $\mathrm{~S}$ \\
\hline Error & 7837.263 & $\begin{array}{c}15 \\
5\end{array}$ & 50.563 & & & \\
\hline Total & $\begin{array}{c}635250.00 \\
0\end{array}$ & $\begin{array}{c}15 \\
9\end{array}$ & & & & \\
\hline $\begin{array}{c}\text { Correcte } \\
\text { d Total }\end{array}$ & 25045.597 & $\begin{array}{c}15 \\
8\end{array}$ & & & & \\
\hline
\end{tabular}

Table 4 shows that at 0.05 level of significance, $1 \mathrm{df}$ numerator and $158 \mathrm{df}$ denominator, the calculated $\mathrm{F}$ is 157.585 with Pvalue of 0.000 which is less than 0.05 . Therefore, the null hypothesis was rejected. Thus, there is a significant difference in the mean interest scores of students in biology taught using discovery learning and problem-based learning and those taught using conventional method. The order of significance is shown in Table 12.
Table 5: Scheffe PostHoc on Differences in the Mean Interest Scores of Students taught using DL, PBL and those taught CM

\begin{tabular}{|c|c|c|c|c|}
\hline $\begin{array}{c}(\mathrm{I}) \\
\text { Method }\end{array}$ & $\begin{array}{c}(\mathrm{J}) \\
\text { Method }\end{array}$ & $\begin{array}{c}\text { Mean } \\
\text { Difference } \\
(\mathrm{I}-\mathrm{J})\end{array}$ & $\begin{array}{c}\text { Std. } \\
\text { Error }\end{array}$ & Sig. $^{\mathrm{b}}$ \\
\hline \multirow{2}{*}{ DL } & PBL & $10.121^{*}$ & 1.448 & .000 \\
\cline { 2 - 5 } & CM & $26.343^{*}$ & 1.527 & .000 \\
\hline \multirow{2}{*}{ PBL } & DL & $-10.121^{*}$ & 1.448 & .000 \\
\cline { 2 - 5 } & CM & $16.222^{*}$ & 1.334 & .000 \\
\hline \multirow{2}{*}{ CM } & DL & $-26.343^{*}$ & 1.527 & .000 \\
\cline { 2 - 5 } & PBL & $-16.222^{*}$ & 1.334 & .000 \\
\hline \multicolumn{5}{|c|}{ Based on estimated marginal means } \\
\hline \multirow{2}{*}{ *. The mean difference is significant at the .05} \\
level. \\
\hline
\end{tabular}

Table 5 reveals that significant difference exists between the mean interest scores of students taught using DL and those taught using PBL in favour of those with DL. Table 5 also reveals that a significant difference exists between the mean interest scores of students taught with DL and those taught using $\mathrm{CM}$ in favour of DL. Table 5 furthershows that significant difference exists between the mean interest scores of those taught with PBL and those taught using CM in favour of PBL.

Hypothesis 2: There is no significant difference in the mean interest scores of male and female students in Biology taught using discovery learning.

Hypothesis two was answered using analysis of covariance and presented in Table 6.

Table 6: ANCOVA on test of Significant Difference in the Mean Interest Score of Male and Female Students taught Biology using Discovery Learning

\begin{tabular}{|c|c|c|c|c|c|c|}
\hline $\begin{array}{c}\text { Source of } \\
\text { variation }\end{array}$ & SS & $\begin{array}{c}\mathrm{D} \\
\mathrm{f}\end{array}$ & $\mathrm{MS}$ & $\mathrm{F}$ & $\begin{array}{c}\text { P- } \\
\text { valu } \\
\mathrm{e}\end{array}$ & $\begin{array}{c}\text { Decisio } \\
\mathrm{n}\end{array}$ \\
\hline $\begin{array}{c}\text { Correcte } \\
\text { d Model }\end{array}$ & $4.399^{\mathrm{a}}$ & 2 & 2.199 & .162 & .851 & \\
\hline Intercept & 17491.270 & 1 & $\begin{array}{c}17491.27 \\
0\end{array}$ & $\begin{array}{c}1287.83 \\
7\end{array}$ & .000 & \\
\hline Pretest & 4.397 & 1 & 4.397 & .324 & .573 & \\
\hline Gender & .005 & 1 & .005 & .000 & .985 & $\mathrm{NS}$ \\
\hline Error & 543.276 & 40 & 13.582 & & & \\
\hline Total & $\begin{array}{c}240925.00 \\
0\end{array}$ & 43 & & & & \\
\hline $\begin{array}{c}\text { Correcte } \\
\text { d Total }\end{array}$ & 547.674 & 42 & & & & \\
\hline
\end{tabular}

Table 6 shows that at 0.05 level of significance, $1 \mathrm{df}$ numerator and $42 \mathrm{df}$ denominator, the calculated $\mathrm{F}$ is 0.000 with Pvalue of 0.985 which is greater than 0.05 . Therefore, the null hypothesis was not rejected. Thus, there is no significant difference in the mean interest scores of male and female students in Biology taught using discovery learning.

Hypothesis 3: There is no significant difference in the mean interest scores of male and female students in Biology taught using problem based learning.

Hypothesis three was answered using analysis of covariance and presented in Table 7. 
Table 7: ANCOVA on test of Significant Difference in the Mean Achievement Score of Male and Female Students taught Biology using Discovery Learning

\begin{tabular}{|c|c|c|c|c|c|c|}
\hline $\begin{array}{c}\text { Source of } \\
\text { variation }\end{array}$ & SS & Df & MS & F & $\begin{array}{c}\text { P- } \\
\text { value }\end{array}$ & Decision \\
\hline $\begin{array}{c}\text { Corrected } \\
\text { Model }\end{array}$ & $4159.446^{\mathrm{a}}$ & 2 & 2079.723 & 44.041 & .000 & \\
\hline Intercept & 26757.882 & 1 & 26757.882 & 566.632 & .000 & \\
\hline Pretest & .162 & 1 & .162 & .003 & .954 & \\
\hline Gender & 4119.391 & 1 & 4119.391 & 87.233 & .000 & S \\
\hline Error & 2738.915 & 58 & 47.223 & & & \\
\hline Total & 263325.000 & 61 & & & & \\
\hline $\begin{array}{c}\text { Corrected } \\
\text { Total }\end{array}$ & 6898.361 & 60 & & & & \\
\hline
\end{tabular}

Table 7 shows that at 0.05 level of significance, $1 \mathrm{df}$ numerator and 60df denominator, the calculated F is 87.233 with Pvalue of 0.000 which is less than 0.05 . Therefore, the null hypothesis was rejected. Thus, there is significant difference in the mean interest scores of male and female students in Biology taught using problem based learning.

Hypothesis 4: There is no significant interaction effect of teaching methods and gender on interest of students in Biology.

Hypothesis four was answered using analysis of covariance and presented in Table 8.

Table 8: ANCOVA on Interaction Effect of Teaching Methods and Gender on Student' Interest in Biology

\begin{tabular}{|c|c|c|c|c|c|c|}
\hline $\begin{array}{c}\text { Source } \\
\text { of } \\
\text { variation }\end{array}$ & SS & Df & MS & F & $\begin{array}{c}\text { P- } \\
\text { valu } \\
\mathrm{e}\end{array}$ & $\begin{array}{c}\text { Decisio } \\
\mathrm{n}\end{array}$ \\
\hline $\begin{array}{c}\text { Correcte } \\
\text { d Model }\end{array}$ & $21348.894^{\mathrm{a}}$ & 6 & 3558.149 & 146.303 & .000 & \\
\hline Intercept & 60247.187 & 1 & $\begin{array}{c}60247.18 \\
7\end{array}$ & $\begin{array}{c}2477.22 \\
6\end{array}$ & .000 & \\
\hline Pretest & .258 & 1 & .258 & .011 & .918 & \\
\hline Method & 14980.908 & 2 & 7490.454 & 307.990 & .000 & \\
\hline Gender & 1235.478 & 1 & 1235.478 & 50.800 & .000 & \\
\hline $\begin{array}{c}\text { Method } \\
* \text { Gender }\end{array}$ & 2567.394 & 2 & 1283.697 & 52.783 & .000 & $\mathrm{~S}$ \\
\hline Error & 3696.704 & $\begin{array}{c}15 \\
2\end{array}$ & 24.320 & & & \\
\hline Total & 635250.00 & $\begin{array}{c}15 \\
9\end{array}$ & & & & \\
\hline $\begin{array}{c}\text { Correcte } \\
\mathrm{d} \text { Total }\end{array}$ & 25045.597 & 8 & & & & \\
\hline
\end{tabular}

Table 8 shows that at 0.05 level of significance, $1 \mathrm{df}$ numerator and $158 \mathrm{df}$ denominator, the calculated F is 52.783 with Pvalue of 0.000 which is less than 0.05 . Therefore, the null hypothesis was rejected. Thus, there is significant interaction effect of teaching methods and gender on interest of students in Biology. The interaction is shown in interaction plot in Figure 3.

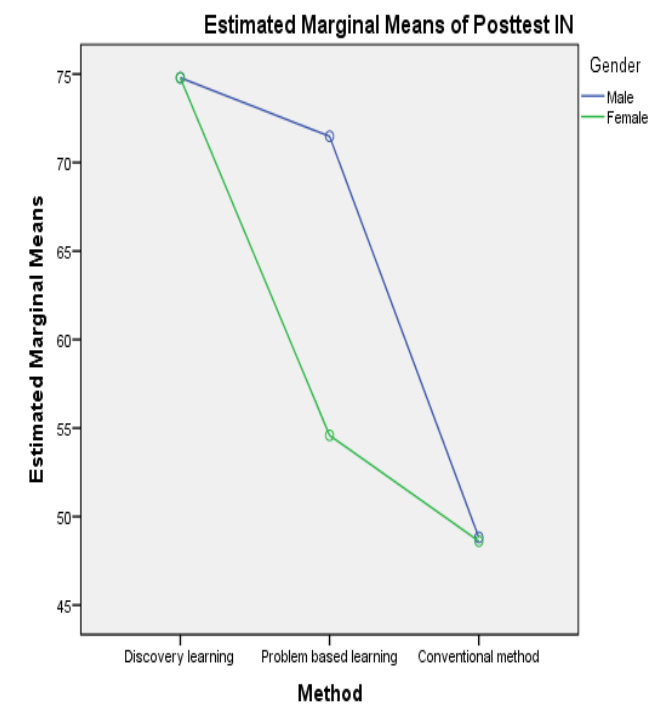

Covariates appearing in the model are evaluated at the following values: Pretest $\mathbb{I N}=21.07$

Figure 1: Interaction Plot of Teaching Methods and Gender on Interest of Students in Biology

\section{DISCUSSION}

The findings of the study showed that discovery learning significantly improved students' interest more than problembased learning and conventional method. The observed difference in interest is because, discovering new knowledge interests and fascinates the learner. When they imagined that on their own or on the guidance of the teacher, were able to discover what they did not know before, the learning become all the more interesting to them. With the rise in interest, students engaged in more learning activities to discover more and more knowledge resulting in heightened interest towards learning.

The finding of the study further revealed that problem-based learning significantly improved interest in learning than conventional method. The observation could be attributed to the same reason as those in the discovery learning group where learning new knowledge resulted in improved interest in learning. Students who consistently solved problem and amidst trials and errors acquired skills to solve problems correctly have their interest in learning increased. The resultant new level of interest is because they are trying to solve a problem which drove them to seek the requite skills. When they solved a problem correctly, they become interested in seeing if the new knowledge and skills could help them solve other similar problems. The seeming zeal to apply skills in the solution to other problems or other such related problems is what may have resulted in significantly improved interest in learning among the students taught using problembased learning than among students taught using conventional method.

The findings of the study contradicts the findings of Oziokor (2015) that there was also significant difference in the interest of students taught using guided discovery method and those 
taught using lecture method in favour of lecture method. The findings of study by Datom (2015) that guided discovery improved interest significantly better than lecture method, support the finding of the study. The findings of the study also support that of Hussain and Umar (2012) that a significant difference in the interest of the students exposed to CAI and the traditional lecture method in favour of CAI.

The findings of the study showed that there was no significant difference between the mean interest scores of male and female students taught using discovery learning. However, significant difference was observed between the interest scores of male and female students taught biology using problem-based learning. Significant interaction effect was also observed. The use of discovery learning equally affected the interest of students in learning biology. This is because, the method was as much engaging for male students as it was for female students. On the other hand, problembased learning aroused the interest of male students more than it did for female students. It was observed that female students saw the method as too engaging. They were often given problem to solve, for which they saw the learning process as tasking while male students took advantage of the strategy.

\section{CONCLUSION}

It can be concluded based on the findings of the study that discovery learning significantly improves students' interest in biology. The study also concludes that discovery learning is more effective than problem-based learning in arousing and sustaining students' interest in learning biology.

\section{RECOMMENDATIONS}

The following recommendations are made based on the findings of the study:

1. Orientation and seminars should be organized by school administrators for biology teachers to aid them in the mastery of discovery and problem-based learning and how to integrate them in the learning process of biology.

2. In adopting problem-based learning, teachers should plan the lesson in such a way that both male and female students are equally engaged in the learning process.

\section{REFERENCES}

[1] Alfieri, L., Brooks, P. J., Aldrich, N. J., \& Tenenbaum, H. R. (2011). Does discovery-based instruction enhance learning? Journal of Educational Psychology, 10 (3), pp. 1-18.

[2] Barrows, H. S. (2000). Problem-based learning applied to medical education. Springfield, IL: Southern Illinois University School of Medicine.

[3] Cambell, N.A. (2015). Biology (4thed.). United Kingdom: The Benjamin Cumming.

[4] Datom, A. N. (2015).Effectiveness of demonstration and guided discovery methods oninterest and achievement of upper basic science students in Taraba State, Nigeria. Unpublished Master's Thesis, Ahmadu Bello University, Zaria

[5] Erickson, B.L., Peters, C. \& Strommer, D.W. (2006). Teaching First-Year College Students Revised and Expanded Edition of Teaching College Freshmen. International Journal for the Scholarship of Teaching and Learning 3(1), pp. 12 - 36

[6] Hmelo-Silver, C. E. (2004). Problem-based learning: What and how do students learn? Educational Psychology Review, 235-266.

[7] Hussain, L., \& Umar, A. (2012).Role of CAI on the interest and retention of students at secondary school level. Academic Research International, 3(2), $336-345$.

[8] Jonassen D. H., \& Hung, W. (2012). Problem-based learning. In: N. M. Seel (Ed.), Encyclopedia of the Sciences of Learning, pp. 2687-2690.

[9] Mader, S.S. (2017). Biology: ( ${ }^{\text {th }}$ ed.) New Mexico: McGraw-Hill Publisher.

[10] Mattingly, C., Lutkehaus, N.C., \& Throop, C.J. (2008). Bruner's search for meaning: A conservation between psychology and anthropology. Ethos, 36, 1-28.

[11] Oziokor, C. C. (2015). Effect of guided discovery method on academic achievement and interest of senior secondary school students in food and nutrition in Nsukka education zone of Enugu State.(Unpublished M.ED Thesis)University of Nigeria, Nsukka.

[12] Udo, M. E. (2010). Effect of guided discovery, students-centred demonstration and the expository instructional strategies on students' performance in chemistry. An International MultiDisciplinary Journal, Ethiopia, 4(4), 389-398.

[13] Wood, D. (1975). A Study of Assisted Problem-Solving. British Journa of Psychology. 66 (2), pp. 181-191

[14] Yoon, H., Woo, A. J., Treagust, D.F., \& Chandrasegaran, A.L. (2014). The efficacy of problem-based learning in an analytical laboratory course for preservice chemistry teachers. International Journal of Science Education, 36 (1), 79-102.

[15] Zejnilagic-Hajric, M., Sabeta, A., \& Nuic, I. (2015). The effects of problem-based learning on students' achievements in primary school chemistry. Bulletin of the Chemists and Technologists of Bosnia and Herzegovina, 44, 17-21. 